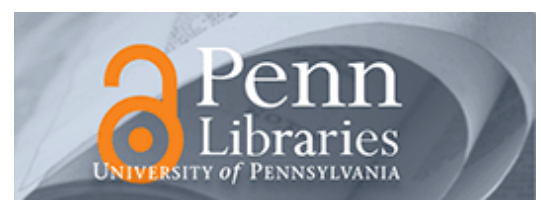

Manuscript Studies

\title{
In the Age of Non-Mechanical Reproduction: Manuscript Variation in Early-Modern South Asia
}

Arthur Dudney

University of Cambridge

Neeraja Poddar

The City Palace Museum, Udaipur, and Oxford Centre for Hindu Studies

Follow this and additional works at: https://repository.upenn.edu/mss_sims

Part of the Ancient, Medieval, Renaissance and Baroque Art and Architecture Commons, Asian Art and Architecture Commons, Asian History Commons, Renaissance Studies Commons, and the South and Southeast Asian Languages and Societies Commons

\section{Recommended Citation}

Dudney, Arthur and Poddar, Neeraja (2019) "In the Age of Non-Mechanical Reproduction: Manuscript Variation in Early-Modern South Asia," Manuscript Studies: Vol. 4 : Iss. 1 , Article 1.

Available at: https://repository.upenn.edu/mss_sims/vol4/iss1/1 
In the Age of Non-Mechanical Reproduction: Manuscript Variation in EarlyModern South Asia

\section{Keywords}

Manuscript studies, South Asia, early-modern, transmission, copying, reproduction, circulation, pothi, codex, book history, manuscript variation, plagiarism, Persian, intertextuality, manuscript, painting, illustration 


\section{MANUSCRIPT STUDIES}

A Journal of the Schoenberg Institute for Manuscript Studies

VOLUME 4, NUMBER 1

(Spring 2019)

Manuscript Studies (ISSN 2381-5329) is published semiannually

by the University of Pennsylvania Press

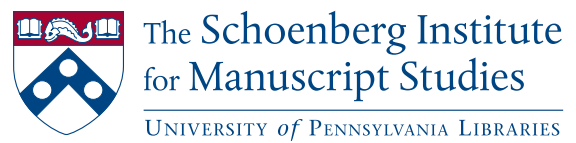




\section{Manuscript Studies, Vol. 4 [2019], Iss. 1, Art. 1}

\section{MANUSCRIPT STUDIES}

VOLUME 4, N U M B E R 1

(Spring 2019)

ISSN 2381-5329

Copyright (C) 2019 University of Pennsylvania Libraries

and University of Pennsylvania Press. All rights reserved.

Published by the University of Pennsylvania Press, 3905 Spruce Street, Philadelphia, PA 19104.

Printed in the U.S.A. on acid-free paper.

Manuscript Studies brings together scholarship from around the world and across disciplines related to the study of premodern manuscript books and documents, with a special emphasis on the role of digital technologies in advancing manuscript research. Articles for submission should be prepared according to the Chicago Manual of Style, $16^{\text {th }}$ edition, and follow the style guidelines found at http://mss.pennpress.org.

None of the contents of this journal may be reproduced without prior written consent of the University of Pennsylvania Press. Authorization to photocopy is granted by the University of Pennsylvania Press for libraries or other users registered with Copyright Clearance Center (CCC) Transaction Reporting Service, provided that all required fees are verified with CCC and paid directly to CCC, 222 Rosewood Drive, Danvers, MA 01923. This consent does not extend to other kinds of copying for general distribution, for advertising or promotional purposes, for creating new collective works, for database retrieval, or for resale.

\section{SUBSCRIPTION INFORMATION:}

Single issues: $\$ 30$

Print and online subscriptions: Individuals: $\$ 40$; Institutions: $\$ 92$; Full-time Students: $\$ 30$ International subscribers, please add $\$ 18$ per year for shipping.

Online-only subscriptions: Individuals: $\$ 32$; Institutions: $\$ 80$

Please direct all subscription orders, inquiries, requests for single issues, address changes, and other business communications to Penn Press Journals, 3905 Spruce Street, Philadelphia, PA 19104. Phone: 215-573-1295. Fax: 215-746-3636. Email: journals@pobox.upenn.edu. Prepayment is required. Orders may be charged to MasterCard, Visa, and American Express credit cards. Checks and money orders should be made payable to "University of Pennsylvania Press" and sent to the address printed directly above.

One-year subscriptions are valid January 1 through December 31. Subscriptions received after October 31 in any year become effective the following January 1. Subscribers joining midyear receive immediately copies of all issues of Manuscript Studies already in print for that year.

Postmaster: send address changes to Penn Press Journals, 3905 Spruce Street, Philadelphia, PA 19104.

Visit Manuscript Studies on the web at mss.pennpress.org. 


\section{MANUSCRIPT STUDIES}

\section{A Journal of the Schoenberg Institute for Manuscript Studies}

VOLUME 4, N UMBER 1

\section{Articles}

In the Age of Non-Mechanical Reproduction:

Manuscript Variation in Early-Modern South Asia

Arthur Dudney, Neeraja Poddar

Manuscript Variations of Dabistān-i Mažāhib

and Writing Histories of Religion in Mughal India

Sudev Sheth

Power Permutations in Early Hindi Manuscripts:

Who Asks the Questions and Who Gives the Answers,

Rāmānand or Kabīr?

Heide Paunels

The Strange Afterlife of Vidyāpati Thākura (ca. 1350-1450

$\mathrm{CE}$ ): Anthological Manuscripts, Linguistic Confusion, and Religious Appropriation

CHRistopher L. DiAmond

Prefatory Notes on Persian Idioms of Islamic Jurisprudence:

Reasoning and Procedures of Law-Making in Premodern

Islamicate India

Naveen Kanalu

Replication and Innovation in the Folk Narratives

of Telangana: Scroll Paintings of the Padmasali

Purana, 1625-2000

Anais Da Fonseca

Nectar or Arrow: Cases of Missense Textual Mutations in Early Kabïrian Padas

Zhang Minyu 
Manuscript Studies, Vol. 4 [2019], Iss. 1, Art. 1

iv | Journal for Manuscript Studies

"Publishing" and Publics in a World Without Print:

Vernacular Manuscripts in Early Modern India

Tyler Williams

\section{Reviews}

Kay Davenport. The Bar Books: Manuscripts Illuminated for Renaud de Bar, Bishop of Metz (1303-1316).

RICHARD A. LESON

Matti Peikola, Aleksi Mäkilähde, Hanna Salmi, Mari-Liisa

Varila, and Janne Skaffari, eds. Verbal and Visual

Communication in Early English Texts.

Lydia Yaitsky KeRTZ

Alpo Honkapohja. Alchemy, Medicine, and Commercial

Book Production: A Codicological and Linguistic Study

of the Voigts-Sloane Manuscript Group.

Winston BLACK

List of Manuscripts Cited 


\title{
In the Age of Non-Mechanical Reproduction: Manuscript Variation in Early-Modern South Asia
}

\author{
ARTHUR DUdNeY \\ University of Cambridge
}

Neeraja Poddar

The City Palace Museum, Udaipur,

and Oxford Centre for Hindu Studies

$\mathrm{H}$

UMANistic SCholarship on South Asia has become increasingly interested in examining culture not as a monolith but as a field where the actors, objects, and ideas are mobile and frequently altered by interactions with each other. ${ }^{1}$ Recent publications in art history, literary studies, history, and religious studies have taken notice of this dynamism and concern themselves with the "circulation of culture-its

1 For example, Finbarr B. Flood, Objects of Translation: Material Culture and Medieval "Hindu-Muslim" Encounter (Princeton, NJ: Princeton University Press, 2009); Patronage and Popularisation, Pilgrimage and Procession: Channels of Transcultural Translation and Transmission in Early Modern South Asia, ed. Heidi Pauwels (Wiesbaden: Harrassowitz, 2009); IndoMuslim Cultures in Transition, ed. Alka Patel and Karen Leonard (Leiden: Brill, 2011); Culture and Circulation: Literature in Motion in Early Modern India, ed. Allison Busch and Thomas de Bruijn (Leiden: Brill, 2014); After Timur Left: Culture and Circulation in Fifteenth-Century North India, ed. Francesca Orsini and Samira Sheikh (New Delhi: Oxford University Press, 2014). 
producers, products, and practices."2 As opposed to privileging an "original" avatar with a fixed meaning, which has been the fate of many itinerant objects and texts that have previously been studied, scholars have begun to probe the layers of meaning acquired by texts and objects that move across time, place, and contexts, their mobility forming them into hybrid products shaped from myriad points of contact. ${ }^{3}$ These objects and texts are frequently treated as sites where the interface between cultures can be traced; a large proportion of new scholarship on such questions is focused on the encounter of Indic artistic and literary idioms and practices with Islam.

The introduction and articles in this special issue, which began as a panel we organized at the European Conference on South Asian Studies at the University of Warsaw in 2016, add to this literature on circulation. But they shift the emphasis away from mobility and cross-cultural exchange and concern themselves primarily with "multiples"-the multiple iterations, versions, interpretations, and uses of a text or artwork that facilitate circulation. Concentrating on works in transit, they explore the themes of copying, repetition, and reproduction in the context of early-modern South Asian manuscripts. Included are works in the pothi (loose-leaf), codex, and scroll format, with and without illustrations, and ranging in genre from literature and religious treatises to dictionaries and other reference works. Common to them is the fact that multiple versions and editions of each were made through copying by hand.

Taking into account the somewhat unpredictable nature of human agency, the articles examine the tangible impact of transmission processes on the meaning of a particular work. The result of non-mechanical reproduction is that copies might not be "perfect" because of variations introduced by artists, scribes, and editors, either deliberately or inadvertently, into illustrations and texts. Our purpose is to consider the significance of

2 Busch and De Bruijn, Culture and Circulation, 4.

3 Busch and De Bruijn discuss the long-standing inclination in Indological research to try to find the textual original amid interpolations and additions and the recent attempts to break away from this trend. See Culture and Circulation, 4-7. For a discussion of a hybrid object, see Zirwat Chowdhury, "An Imperial Mughal Tent and Mobile Sovereignty in EighteenthCentury Jodhpur,” Art History 38, no. 4 (2015): 668-81. 
such variations to understand how books were valued, used, and disseminated. Rather than thinking of variations as merely discrepancies or mistakes, we regard them as junctures where the authors' or artists' engagement with contemporary sectarian concerns, literary trends, artistic strategies, and popular culture may be manifest. The questions that have guided our contributors include: What is the core of a text? Which viewpoint is preferred at a particular historical moment? How are narratives transformed as they are copied? What is the impact of scribal error when such an error becomes sanctified by usage? To what degree was a pre-modern author thought of as the owner of his or her work? What purchase does our understanding of intertextuality and plagiarism have in the past? Woven through the articles is a deliberation on agency-how do we ascribe agency to copyists, editors, scribes, and other persons who are not the "creators" of a work but nevertheless have an impact on its meaning?

In its exploration of the mechanics of transmission, we see this issue as contributing to a broader understanding of circulation in early-modern South Asia. The approach adopted by most of our authors-combining a grasp of the contexts in which specific versions were making meaning, with detailed analyses of texts and illustrations-is applicable to multiples produced in a variety of formats and across modern academic disciplines. The different case studies demonstrate similar concerns, stressing the need for and advantage of interdisciplinary dialogue. Moreover, they all advocate a return to objects (in the plural), rather than relying on a single, standardized, published, or original one, as the means to a more complete picture of historical processes.

The benefits of an interdisciplinary approach to multiples will be underscored in this introduction by bringing into dialogue case studies from two apparently very different fields - textual studies and art history. We aim to show that similar questions about multiples can be fruitfully applied as an analytical frame to both Indo-Persian texts and Rajput illustrated manuscripts and series. One major difference we should point out is the more formalized approach to copying in the former, but we perceive an overlap in other issues, including the agency of the copyist, transformation of meaning 
across multiples, and the widespread and multifaceted nature of the practice of copying. Similar threads are also picked up in the articles that follow.

The Persian verse tradition, which connected early-modern South Asia with Iran, Central Asia, and the Ottoman lands as far as the Balkans, institutionalized copying through a system of literary authority. For a metaphor to be considered correct (fașin), a poet generally had to show that it had been previously used by a master poet. ${ }^{4}$ An ever-expanding textual apparatus of literary commentaries, dictionaries, and tazkirabs (biographical compendia) can be understood in part as a collection of such proofs of usage called asnād (sg. sanad). Such texts were in turn fed by collections like a dīwān (an author's selected poems) and poems recorded at literary gatherings in a participant's personal bayāz or notebook (also known by various synonyms, such as safinab, lit. 'a boat'). Thus, canonical sources of a poet's verse coexisted with ad hoc ones like notebooks and even poems scribbled in the flyleaves of manuscripts. Although attested sources were preferred, such scraps of text were pulled into the public consciousness of an author's work and not rejected out of hand even if there was no evidence the person to whom it was attributed actually composed it. ${ }^{5}$ The orality of the tradition, such as the institution of the literary gathering (mushä $\left.\bar{a}^{\mathrm{i}} \mathrm{rab}\right)$, means that physical circulation of manuscripts does not necessarily map onto textual circulation. Poets were known even if, as the writers of some of the comprehensive tazkirabs frequently admit, their dīwāns could not be obtained. This kind of oral circulation and indeed the chopping up of longer works into free-standing couplets are both unfamiliar from our perspective.

4 See Arthur Dudney, "Metaphorical Language as a Battleground for Tradition and Newness in Late Mughal Persian,” International Journal of Persian Literature 2 (2017): 138-60.

5 The problem is even more acute in medieval Hindi. Some of the tradition's most celebrated authors, such as Kabir (fl. fifteenth century) and Surdas (fl. sixteenth century), have vast bodies of works bearing their names, but they most likely did not compose a large proportion of these poems. Devotees of Surdas would invoke the master's chāp (poetic signature, of which the Persian/Urdu equivalent is takballus) in their own compositions, effectively making him a character in poems whose authorship would be attributed to the master in the manuscript and performative tradition. See John Stratton Hawley, Three Bhakti Voices: Mirabai, Surdas, and Kabir in Their Times and Ours (Delhi: Oxford University Press, 2005), 21-47. 
In the Indo-Persian tradition, the difference between adaptation and plagiarism was sometimes subtle, hair-splitting even, but adaptation in various forms was seen as necessary for a healthy literary tradition, while sariqab or plagiarism was considered an offense against both good taste and the poet whose work was taken. Engaging with earlier poets is described as istiqbāl, which is literally the idea of "welcoming" a poetic predecessor into the present. ${ }^{6}$ The usual literary device for such a welcome is tazminnamely, quoting from an earlier poet and replying to the quotation. ${ }^{7}$ Plagiarism was frequently debated, and it was important to determine whether the poet was aware of what he was doing: Did he remember someone else's poetry subconsciously and accidentally pass it off as his own? In a tradition based in orality, this was a constant danger. ${ }^{8}$ The unit of analysis in Persian lyric poetry is not the whole poem but the couplet, and couplets were often recorded out of order in different manuscript recensions, which demonstrates that poets' memories were a cloud of remembered couplets rather than remembered poems. Or, far worse than accidentally claiming someone else's work, did the plagiarist know the couplet was someone else's and expect to be able to hoodwink his audience, who might be unaware of its true provenance? This sort of plagiarism was obviously an implicit insult to the audience. Of course, in either kind of plagiarism, there was a gray area that generated considerable critical discussion-namely, in which the lines are similar in theme or wording but not identical. Because of this ambiguity, plagiarism as an accusation was often leveled against poets who were perceived as deficient in other ways. In the early 1740s, for example, in a well-documented case in Delhi, the Iranian émigré Shaikh Muhammad 'Ali Hazin was accused of plagiarism by the son of a poet whose work he had denigrated.

6 See Paul E. Losensky, Welcoming Fighānī: Imitation and Poetic Individuality in the Safavid-Mughal Ghazal (Costa Mesa: Mazda, 1998), esp. 100-133 and 193-249.

7 The word tazmin derives from the Arabic root $z-m-n$. Several words from that root have to do with security deposits and guarantees. There is a semiotic echo implying that tazmin is a kind of protection of earlier poets' works.

8 On the implications of orality for the Persian tradition, a hitherto neglected topic, see Nathan Tabor, “A Market for Speech: Poetry Recitation in Late Mughal India, 1690-1810,” Ph.D. dissertation, University of Texas at Austin, 2014. 
The question of literary self-plagiarism does not have any purchase in the tradition. Poets were freely able to draw upon their own earlier works to a degree that strikes us as almost comical. There are several famous instances in which a Persian poem originally written for one patron was repurposed and a new patron's name was substituted with no change to the content of the description of the patron's virtues. ${ }^{9}$ Poetical works that purport to describe a particular place frequently have the name of the place changed in different manuscripts. Changing either the patron or the place described is not as much of a problem as it might seem because of course the poetry was not descriptive in the way that we typically expect poetry to be. It was a different matter if a patron felt as though he were not getting his money's worth. ${ }^{10}$

So much for literary texts. The reuse of Persian analytical works was based in an entirely different principle that strikes us as surprisingly lax by today's standards of version control. Works like dictionaries and tazkirabs, which are compendia of brief biographies of poets along with snippets of their poetry, were frequently expanded or condensed by copyists without any comment. Any tazkirab with a large number of entries will likely appear in different manuscripts in different lengths. A tazkirab could be shortened by simply leaving out entries or reducing the number of quotations for certain poets. It is hard to establish a pattern for why, for example, Khan-i Arzu's tazkirab Majma' un-Nafä’is (Collection of Precious Things, 1753-54) should have approximately 1,400 entries in the supposedly complete Bodleian manuscript (MS Elliot 399) and 1,835 in the Khuda Bakhsh library manuscript (MS 695). ${ }^{11}$ Different recensions of other texts, however, do sometimes show a clear pattern of preferring local poets or older poets or newer poets, and simply cut some entries for poets that are not relevant. Since tazkirabs as a genre are concerned with building the memory of a

9 For examples, see Roy P. Mottahedeh, "Finding Iran in the Panegyrics of the Ghaznavid Court," in Medieval Central Asia and the Persianate World: Iranian Tradition and Islamic Civilisation, ed. A. C. S. Peacock and D. G. Tor (London: I. B. Tauris, 2015).

10 Abdelfattah Kilito, The Author and His Doubles: Essays on Classical Arabic Culture, trans. Michael Cooperson (Syracuse, NY: Syracuse University Press, 2001), 28-31.

11 Abid Reza Bidar, ed., Majma' un-Nafā’is (Patna: Khuda Bakhsh Library, 1970), 2. 
poetic community, real or imagined, then obviously the material in them is determined by the editor's or copyist's interest in shaping memory. ${ }^{12}$ When a tazkirab is lengthened, the addition of entries for new poets is somewhat rare, but far more frequently quotations are amplified for the existing entries. The Persian poetic tradition represented itself as being primarily oral, so it was trivial for the copyist to simply add lines attributed to a particular poet from memory or from other tazkirabs or to strike out lines that did not sound like they were written by a particular poet.

Certain technical texts were reworked and embedded almost in full into other texts, with new authors taking credit for old works. The introductory material describing Persian grammar in the dictionary Farbang-i Jabāngīri was used as a school primer but also formed the basis for the dialectology of Persian provided by Khan-i Arzu in his philological magnum opus Musmir. In some instances, entire dictionaries were reworked (e.g., realphabetized) and embedded into other dictionaries. Here an eighteenth-century dictionary of Indic words written in Persian is a good example: Gंharäỉ al-Lug் $\bar{a} t$ (Oddities Among Words) was originally written by 'Abdul Wasi' Hansawi in the late seventeenth or early eighteenth century and was revised by Khan-i Arzu in 1742 under the title Nawādir al-Alfāz. (Wonders Among Words). Arzu reordered the lexemes (headwords) according to a better alphabetization system but kept every lexeme from the original, noting those that were not of Indic origin and so should not have been included in the first place. Often, phrases like "dar risālah mī-gūyad" ("In the treatise, it says ...") serve as quotation marks demonstrating where text from the original has been embedded in the revised version. If we consider the manuscript tradition, in which the new work more often than not goes under the original title even though very few manuscripts of 'Abdul Wasi's original text survive, then it is clear that the original effectively ceases existing once a better version comes along. Indeed, while this is an extreme example,

12 The word tazkirab derives from the Arabic root $\underline{z}-k-r$, which has to do with memory. See Marcia K. Hermansen and Bruce B. Lawrence, "Indo-Persian Tazkiras as Memorative Communications," in Beyond Turk and Hindu: Retbinking Religious Identities in Islamicate South Asia, ed. David Gilmartin and Bruce B. Lawrence (Gainesville: University Press of Florida, 2000), 150. 
virtually all Persianate philological scholarship worked along similar lines: Many old scholarly texts were not themselves read but rather accessed through later quotations in other works or commentaries. It is worthwhile to trace such indirect readings in different fields, at the very least as a way of redressing the Orientalist obsession with "original" sources and suspicion of interpretations. The marginal commentary is also getting its due as a site of innovation alongside the textual repetition that comes with including the commented-upon text (matn). ${ }^{13}$

In both literature and scholarly works in Indo-Persian, there was intertextuality that our ideas of authorial ownership do not map onto well. Copyists clearly had agency, at least for nonfiction works like dictionaries and other compendia in which they could add or subtract as necessary. When writing verse, a poet had to engage closely with a tradition, sometimes toeing a thin line separating homage from outright theft. The context of contemporary literary debates is therefore important, because it is not helpful for us to apply our own standards as a universal measure of good and bad borrowing.

In art history as well, it is helpful to remember that the contemporary celebration of individual, artistic, creative genius and its concomitant denigration of the copy might not have been shared by artists, patrons, and viewers in the past. ${ }^{14}$ The tension that modern scholars sense between creativity and copying was probably perceived differently in early-modern South Asia, where copying was an accepted aspect of workshop practice.

The attitude to copying in the Persian verse tradition-the valorization of intertextual engagement-often maps onto the visual arts. A. Adamova concludes that the artist copying the illustrated Khamsab of Nizami for the Timurid ruler Shahrukh (1431) was showcasing his virtuosity by copying the paintings in the manuscript with varying degrees of exactitude while

13 See, e.g., Asad Q. Ahmed and Margaret Larkin, "The Hāshiya and Islamic Intellectual History," Oriens 41 (2013): 213-16, and Naveen Kanalu's article in this journal.

14 The problem is discussed in Rosalind Krauss, "The Originality of the Avant-Garde," in her The Originality of the Avant-Garde and Other Modernist Myths (Cambridge, MA: MIT Press, 1985), 151-70. 
inventing new compositions for the most popular subjects. ${ }^{15}$ Copying the work of past masters was an essential aspect of training as well as a means to gauge the merit of the contemporary practitioner. ${ }^{16}$ The ability to copy well was an important tool in the artistic (and calligraphic) repertoire, recognized as such by the patron, who possibly took pleasure in making the connection between the earlier work and its reinterpretation.

In the South Asian context, no extant, formalized rules related to copying are linked to the paintings and illustrated manuscripts produced at the Rajput and Central Indian courts during the early modern period. But a wealth of material, in the form of both works that display a relationship of copying to each other as well as drawings, pounces, and other items that facilitate copying, attests to the ubiquity of the practice. The evidence points to the fact that artists copied anything from single figures or motifs, occasionally tracing them, to complete manuscripts and series, based on earlier models. Studies show that copying occurred not just within a family or workshop, but often across kingdoms and cultures. An important point to remember in the case of copying in the visual arts is access-usually either the source image or a drawing or tracing of it would have been available to the copy artist, suggesting that some sort of link existed or was forged between the persons involved with the production of the model and its copy. Thus, while perusing the examples of copying discussed here, it is helpful to remember that separate instances are often distinguished by singular reasons and connections, impacted by and impacting the circulation of materials.

By the late sixteenth century, Mughal painters, for example, were reproducing a wide variety of imagery, including some drawn from Persian painting, "to display both their pictorial knowledge and their capacity to transform

15 A. Adamova, "Repetition of Compositions in Manuscripts: The Khamsa of Nizami in Leningrad," in Timurid Art and Culture: Iran and Central Asia in the Fifteenth Century, Studies in Islamic Art and Architecture, Supplements to Muqarnas, vol. 6, ed. Lisa Golombek and Maria Subtelny (Leiden: E. J. Brill, 1992), 67-75.

16 David Roxburgh, The Persian Album, 1400-1600: From Dispersal to Collection (New Haven, CT: Yale University Press, 2005). 
and perhaps improve what they had sourced." ${ }^{17}$ What the artists' efforts also indicate is the myriad cultures whose art was available at the Mughal court. The artists responsible for the Mughal emperor Jahangir's early seventeenth-century album-the Gulshan-reproduced elements from the European works that had been circulating at the court since the previous century. The Mughal artists reused Adonis, Adam, St. Peter, and other figures from European engravings without worrying about their original narrative context. ${ }^{18}$ Such quotation might divest the figure of narrative meaning, but Molly Aitken sees the Gulshan album's significance "as a reflection on sources, skill, and connoisseurship, or more basically, on the pleasures of the art." ${ }^{19}$

Artists working in the Rajput kingdoms of Bundi and Kota repeated Rāgamāla (garland of musical modes) compositions for generations, having access, possibly, to the original works as well as detailed drawings. The urmanuscript for this series was made at Chunar in 1591 for the ruler of Bundi, who was the Mughal representative there. When he returned to his kingdom, either the Chunar manuscript or detailed drawings must have traveled back with him and formed the basis for the later series. According to Vishakha Desai, "what qualifies the later Bundi Rāgamālā sets as copies is the nature of their iconographic as well as their compositional dependence on the model set." ${ }^{20}$ Thus, while most depictions of Vilavala Ragini will share certain features, including a woman seated indoors or on a terrace, adorning herself and gazing at her reflection in a mirror held by a female companion, every instance will not be a copy due to the absence of "compositional dependence" in addition to iconographic similarity. ${ }^{21}$

17 Molly Emma Aitken, "Parataxis and the Practice of Reuse, from Mughal Margins to Mìr Kalān Khān," Archives of Asian Art 59 (2009): 81-103 at 89.

18 Milo Beach, "The Gulshan Album and Its European Sources," Bulletin of the Museum of Fine Arts 63, no. 332 (1965): 63-91.

19 Beach, "The Gulshan Album," 75; Aitken, "Parataxis and the Practice of Reuse," 96.

20 Vishakha N. Desai, "Reflections of the Past in the Present: Copying Processes in Indian Painting," in Perceptions of South Asia's Visual Past, ed. Catherine B. Asher and Thomas R. Metcalf (New Delhi: American Institute of Indian Studies, 1994), 135-47 at 143.

21 Examples of Vilavala (or Bilaval) Ragini are Metropolitan Museum of Art 1985.398.11, Brooklyn Museum 1991.180.8, Art Institute of Chicago 1962.147.14, and Honolulu Museum 
A quick glance at the copies produced at Bundi and Kota over two hundred years will show that even so-called copies are not always identical. Comparing a circa 1680 Vilavala depiction (which resembles the 1591 Chunar version quite closely) with a late eighteenth-century iteration, one might wonder at the connection between the two (figs. 1, 2). The alterations in architectural forms and textiles, placement of the sun and fountain, and the appearance of the women impart to the later work a very different look and feel. Desai sees such variations in architecture, clothing, jewelry, facial types, and other "culturally significant elements" as the artist's attempt to make his copy set a product of its own times, reflecting current trends in attire and so on. ${ }^{22}$ Rarely discussed are alterations made to other, minute details in the paintings that can modify what is conveyed. In the Chunar and circa 1680 paintings, for example, the woman getting dressed adjusts her earring with her right hand and grabs the end of her pigtail with her left. Her face is reflected in the mirror held by her companion, who also holds out a necklace for the first woman to try on. In the late eighteenth-century work, on the other hand, the necklace is gone, as is the hand holding the pigtail, while the fixing of the earring is not explicitly delineated - the hand is placed near the ear, but it does not visibly grasp an earring. The scene of a woman explicitly adorning herself in the earlier work becomes a woman gazing at herself in the mirror in the later one. The copy artist is responsible for the contemporizing updates as well as the shift in meaning. Are all the changes made by the copy artist purposeful? How does the shift in meaning impact the iconography of Vilavala Ragini? ${ }^{23}$

of Art 10731.1. The Chunar manuscript's Vilavala Ragini folio is at Bharat Kala Bhavan Museum Varanasi. Copies after it are Freer|Sackler F1990.10, MFA Boston 67.798, and Brooklyn Museum 1991.180.8. An intermediate drawing is Brooklyn Museum 79.260.8.

22 Desai, "Reflections of the Past in the Present," 143.

23 The text, which Klaus Ebeling considers the literary basis for Rāgamālā paintings in the Rajasthani tradition, describes Vilavala as a woman adorning herself with jewels before a love tryst. She also prays to her god of love and is as beautiful as a blue lotus. See Klaus Ebeling, Ragamala Painting (Basel: Ravi Kumar, 1973), 118-22. 
Manuscript Studies, Vol. 4 [2019], Iss. 1, Art. 1

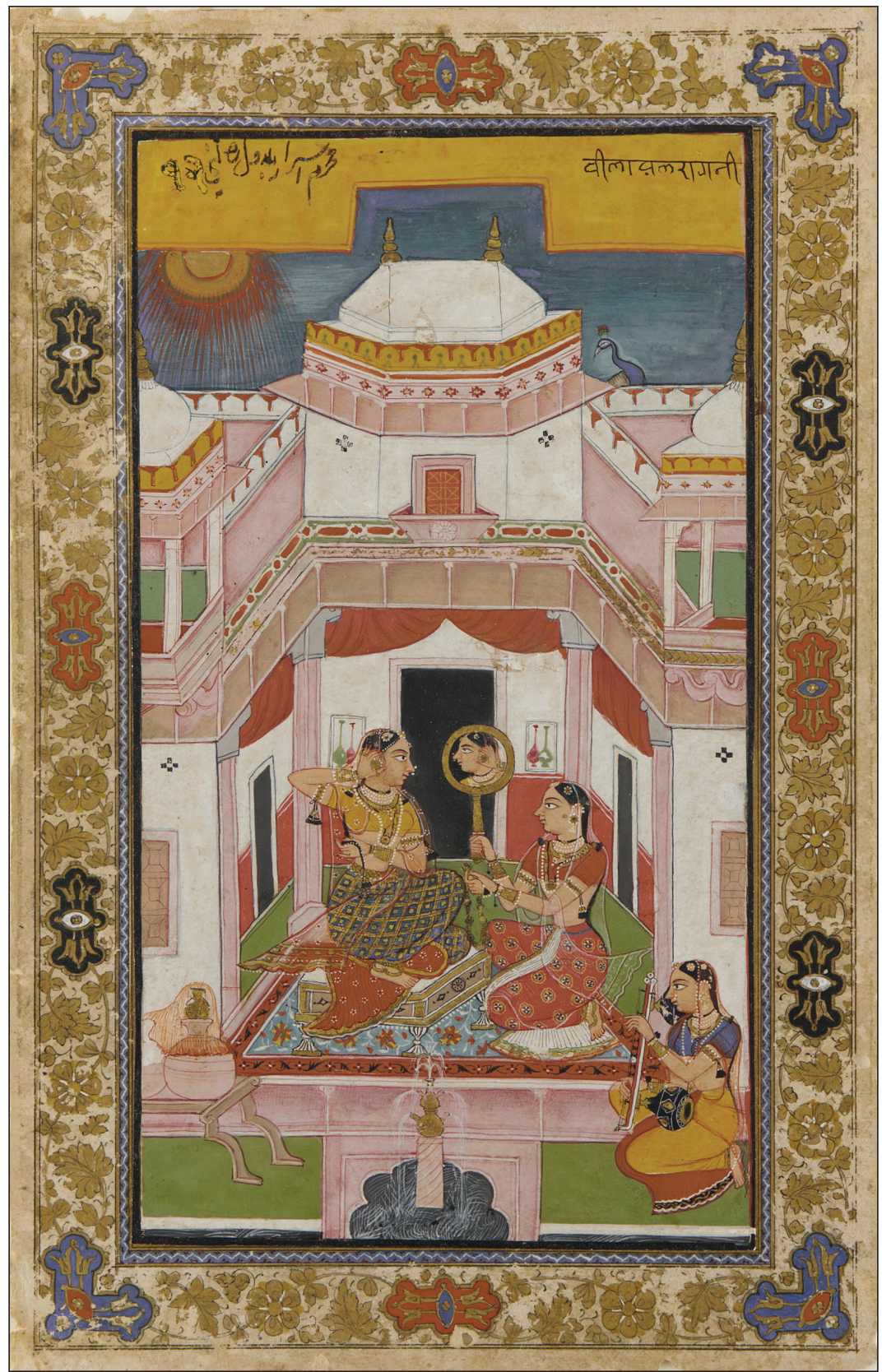

FIGURE 1. Vilavala Ragini, from a Rāgamàlā series. Bundi, circa 1680. Opaque watercolor on paper, $26.2 \times 16.1 \mathrm{~cm}$. Freer Gallery of Art and Arthur M. Sackler Gallery, Smithsonian Institution, Washington, DC: Purchase-Charles Lang Freer Endowment, F1990.10. 
Dudney and Poddar: In the Age of Non-Mechanical Reproduction

Dudney and Poddar, Age of Non-Mechanical Reproduction

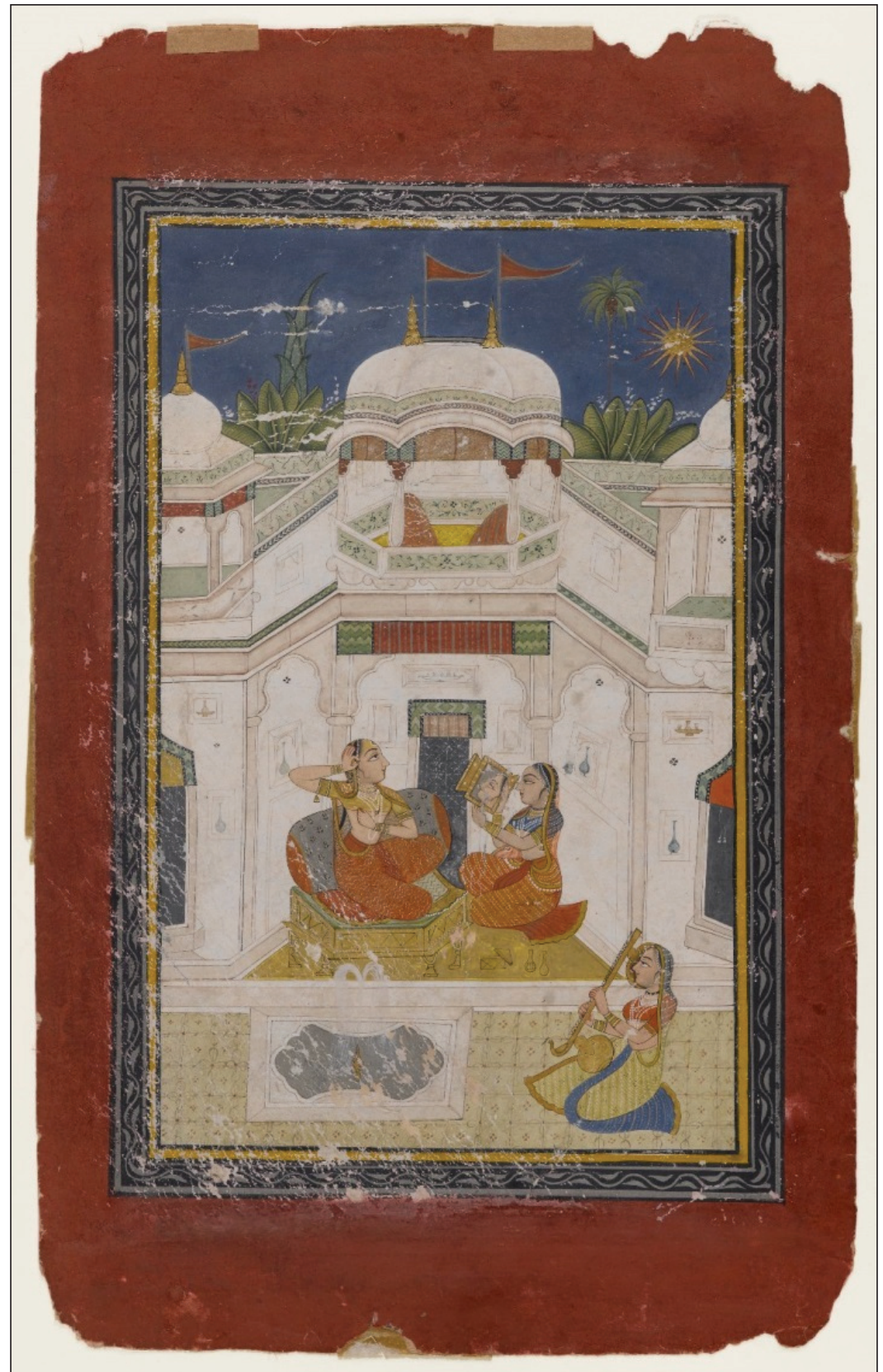

Figure 2. Vilavala Ragini, from a Rāgamālā series. Bundi or Kota, circa 1770-90. Opaque watercolor and gold on paper, sheet: $32.7 \times 20.0 \mathrm{~cm}$. Brooklyn Museum, Gift of Emily Manheim Goldman, 1991.180.8. 
The non-mechanical copying of manuscripts that tell stories, such as the Ràmāyana or the Bhāgavata Purāna, can lead to the introduction of narrative variations in the copy manuscript. An illustrated manuscript of the Latter Half of the Tenth Book of the Bhägavata Purāna, made in Central India and dated to 1688 , acted as the model for at least two later sets. ${ }^{24}$ Comparing the model with its copies, we will notice that the artist imitates with differing degrees of similarity, leading to a lack of consistency in the level of visual correspondence across the 116 folios of the manuscript; it seems the copy artist could exercise some freedom in how he adapted the model. He often changes background colors and clothing and adds golden tufts of grass to the illustrations in the copy sets, imparting to them a richer look. But occasionally, the alterations he introduces impact the narrative and the copy illustration is not as effective in recounting the standardized version of an adventure of Krishna.

To understand how this might happen, we can compare illustrations depicting the events that occur after Krishna defeats Narakasura, a powerful demon who had stolen the royal umbrella of the king of the gods, Indra, and the earrings of Indra's mother Aditi (figs. 3, 4). Krishna sets out on his mount, Garuda, the king of the birds, accompanied by his wife Satyabhama. After defeating Narakasura in a terrific battle, he finds imprisoned in the palace 16,100 maidens, all of whom he decides to marry. These maidens are dispatched to Dwarka, together with riches, horses, and elephants; this is represented in the bottom half of both illustrations with the women traveling in pairs on elephants, chariots, and palanquins. Krishna, in the meantime, heads to the abode of Indra to return the umbrella and earrings he has recovered. In the top left compartment of both illustrations, he is seen seated on Garuda together with Satyabhama, being propitiated by Indra and two women. At the urging of his spouse, Krishna steals a Parijata tree from Indra's garden, and after defeating Indra and others who oppose him, he brings the tree to Dwarka to plant in Satyabhama's mansion. The events related to the Parijata tree can be found in the top right compartment of the illustrations; at

24 For a discussion, see Neeraja Poddar, "Krishna in His Myriad Forms: Narration, Translation and Variation in Illustrated Manuscripts of the Latter Half of the Tenth Book of the Bhāgavata Purāna," Ph.D. dissertation, Columbia University, 2014. 
Dudney and Poddar: In the Age of Non-Mechanical Reproduction

Dudney and Poddar, Age of Non-Mechanical Reproduction | 15

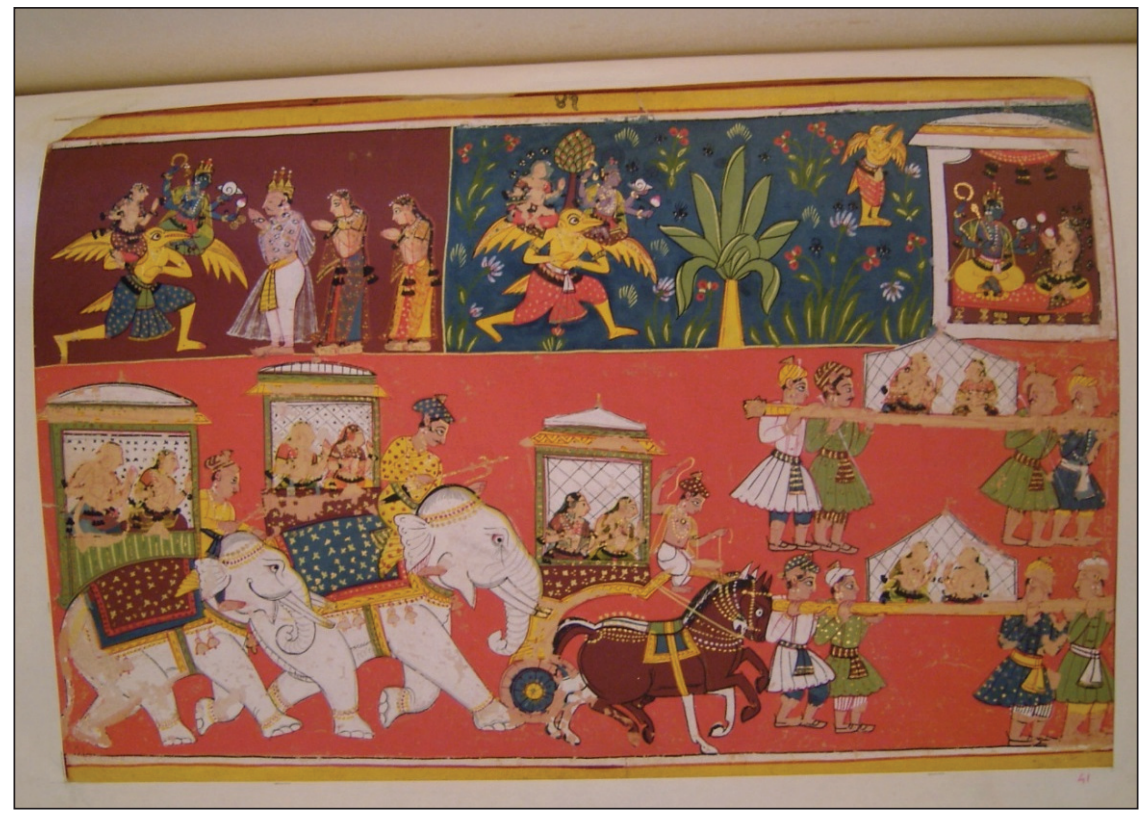

FIGURE 3. Krishna steals the Parijata tree, from a Bhāgavata Purāna manuscript. Central India, 1688. Opaque watercolor on paper, approximately $25 \times 35 \mathrm{~cm}$. Kanoria Collection, Patna.

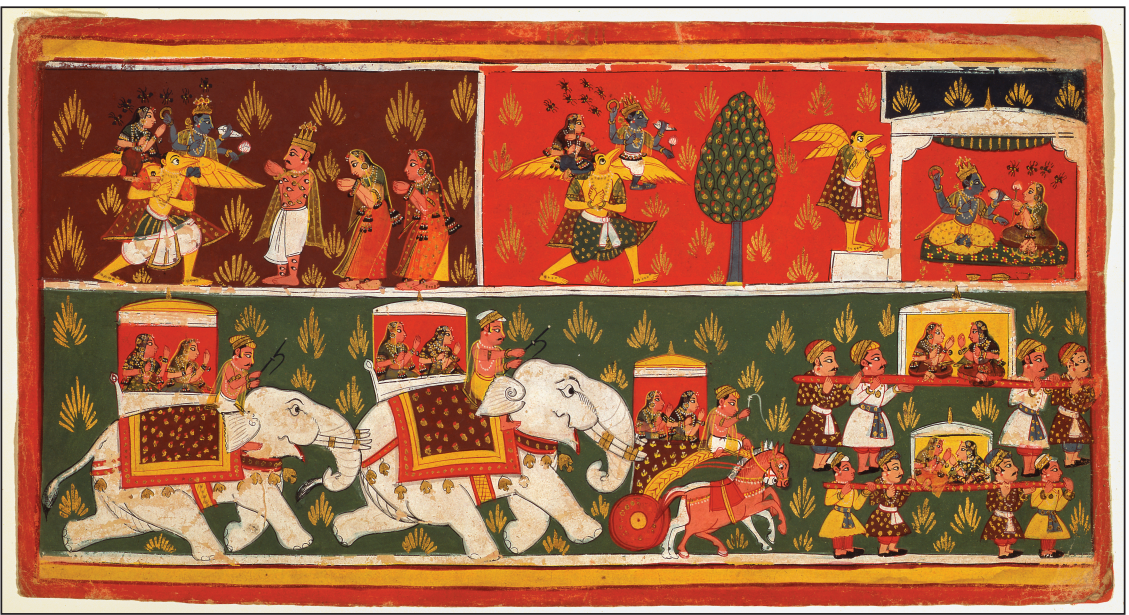

FIGURE 4. Krishna steals the Parijata tree, from a Bhägavata Purāna manuscript. Central India, circa 1700. Ink and opaque watercolors on paper, $19.7 \times 37.1 \mathrm{~cm}$. Asian Art Museum of San Francisco, Gift of George Hopper Fitch, 2010.321. Photograph @ Asian Art Museum of San Francisco. 
the left end of this compartment are Krishna and Satyabhama on Garuda, returning to Dwarka, while on the right they are seated together in a chamber. In the 1688 illustration, as they fly back on Garuda, a miniature tree is depicted between them that is absent in the copy. This miniature tree is in fact the Parijata, and its depiction here reminds us that Krishna has stolen it from heaven and carried it to earth on the back of Garuda. Its absence from the copy eclipses the series of events related to its theft, and we are left with Krishna and Satyabhama simply returning to Dwarka.

Was it the copy artist's intention to erase the Parijata episode? Or did he overlook or not quite understand why the artist had placed the tree on Garuda's back? Other misunderstandings on the part of the copy artist in the context of these manuscripts-switching the scene of a tiger killing a rider to the tiger being killed by the rider-can change the course of the story. Is there a purpose behind the narrative variations introduced? How do such variations impact the manuscript's ability to perform what we regard as one of its main functions: retelling the story? Were the copy manuscripts produced for a different reason where the details of the story did not matter?25 What purchase do the categories of good and bad copying have in the visual arts?

The discussion initiated in the previous section frames the issues taken up in the articles that follow. Four articles address the questions posed through studies of the Hindi ecumene (including adjacent traditions like Maithili and Urdu), one through visual culture in south-central India, and two through the Persian textual heritage of the subcontinent. The order of the articles, however, does not adhere to this classificatory system; they are jumbled to stress the commonalities that come to the surface when language, style, genre, format, and other obvious parallels are put to the side.

Sudev Sheth provides a useful orientation to the topic at hand through his brief history of manuscript production in South Asia, before tracing the

25 These could range from gaining religious merit by patronizing the visualization of Krishna's biography to imitating the actions of a prominent member of a social group. 
book history of the Persian Dabistān-i Mazābib (School of Religions), a seventeenth-century proto-anthropological work. Through his discovery of the earliest known manuscript copy of the Dabistān-i Mazābib, Sheth is able to conclude that later recensions, which are now standardized through scholarly convention, omit details and even entire passages. This helps in confirming the hypothesis that there are actually two versions of the text, and Sheth's article begins to investigate the significance of what is left out or altered between them. Also concerned with multiple recensions of a text, Heidi Pauwels stresses the need to go beyond a standardized, printed version and to engage with the manuscript tradition. Analyzing a dialogue in Hindi between the fifteenth-century poet Kabir and his purported guru Ramanand, Pauwels discusses the often dissimilar outcomes arising in different versions, catching glimpses of the doctrinal positions of the compilers therein. Her conclusion draws parallels with the visual arts, where an image is reproduced in multiple contexts and, as discussed in the previous section, each of its incarnations makes meaning on its own terms.

Christopher Diamond and Naveen Kanalu explore the issue of engagement with a tradition in two very distinct contexts: Diamond considers the multilingual fifteenth-century poet Vidyapati, whose lyrical poems (padas) in the Maithili language had a wide influence as anthologies (padāvalīs). He argues that because these free-standing lyrical poems were not fitted into a larger textual context and were never conceived of as unified textual entities, a stemmatic reconstruction of sources is insufficient. By exploring wider performative contexts, Diamond demonstrates that the Maithili poetic tradition was in constant transregional and translingual dialogue, and that an unbroken connection between later texts and the historical Vidyapati, which has been assumed by literary historians, is unsupported by the evidence. The supposedly "inauthentic" later texts - considered corrupt by scholars because they show evidence of mixing instead of representing a single source-give voice to later writers and audiences who engaged with a body of texts attributed to Vidyapati. Kanalu explores Persian commentaries to Arabic legal works as a site of creative engagement with a tradition. Relatively little is known about the circulation of Arabic texts in the Indian subcontinent and their relationship to Persian texts. Unlike Persian, which was widely used as a language of courtly and bureaucratic culture in South 
Asia, Arabic was used in limited contexts, primarily theology and philosophy. By theorizing the dialogue of Persian commentaries with Arabic legal texts, Kanalu questions the usual narrative that a decline in Islamic legal scholarship had set in due to a slavish adherence to orthodoxy.

By including a discussion of painted scrolls, this special issue shows that similar topics are relevant to a wide range of formats. Anaïs da Fonseca discusses how scrolls narrating the origins of the weavers' caste of Telangana are copied for practical reasons-namely, when the current one is worn out and no longer usable. The copy results from a negotiation between the performer, who guides the narrative, and the painter, who is responsible for style and ensuring the object's religious efficacy. While certain key aspects of the depiction are fixed by convention, others, including costumes, decoration, and ornaments, are often modified. ${ }^{26}$ Zhang Minyu analyzes variation in the padas of Kabir through the textual mutation known as "missense mutation," in which a word is changed but the change yields a plausible reading. Because such changes were transmitted, scribal motivation must be considered alongside factors like slips of the pen.

Drawing upon case studies from both Sufi and Hindu devotional communities, Tyler Williams considers what it meant to "publish" a text in northern India before print. Certain formats of manuscripts appear to have been intended for private use, while others were to be shared among a literary public. To establish which was which, Williams argues, we must be attentive both to primary textual content as well as to paratextual features, especially the physical dimensions of books and the finding aids provided within them. Such an examination of copies of works in different formats addresses the question of a manuscript's imagined community of readers and returns us to the idea of circulation in early-modern North India. As these works were faithfully copied but cast in different formats, their social contexts and interpretative possibilities changed in ways that we can reconstruct.

26 A parallel can be discerned with the copies made after the Chunar Rāgamāa $\bar{a}$, discussed in the previous section. 